\title{
A new comparative study of zooplankton from oceanic, shelf and harbour waters, south-east coast, Jamaica
}

\author{
Kristoffer A Lue and Mona K Webber
}

\begin{abstract}
Background: Zooplankton samples were collected fortnightly from four locations representing oceanic, shelf and harbour waters off Kingston, Jamaica in 2004, approximately 40 years after a similar study was concluded in 1964. The present sampling was conducted using vertical hauls with plankton nets of three different mesh sizes: 64, 200 and $600 \mu \mathrm{m}$ between April and November 2004.

Results: Mean zooplankton abundances across the stations ranged from a maximum $\left(5,858.5\right.$ individuals $\left.\mathrm{m}^{-3}\right)$ at Harbour Shoal Beacon, mouth of Kingston Harbour, to a minimum (2,124.2 individuals $\mathrm{m}^{-3}$ ) at California Bank, an offshore bank. One hundred forty-seven different taxa of zooplankton were identified during this study. Eighty-one taxa were identified from Harbour Shoal Beacon (HSB), 106 from South-East Cay (SEC), 114 from the shelf-edge station, called Windward Edge (WE), and 94 from California Bank (CB). The pattern obtained from the clustering of stations using percent similarity coefficient (PSC) and Jaccard community coefficient (JCC) showed the presence of two distinct groups of stations: one with HSB and the other containing all other stations. The abundance of individual species was also examined for their potential to characterize the different water masses. As found 40 years ago, Lucifer faxoni and Penilia avirostris were indicators of eutrophic Kingston Harbour waters, while Microsetella norvegica and Farranula carinata were identified as indicators of offshore waters. Zooplankton parameters across the area clearly distinguished the eutrophic Kingston Harbour waters from the shelf and offshore sites but could not differentiate between the mesotrophic shelf and the offshore bank. Larval forms were numerically dominant across all stations with copepod nauplii, fish eggs and echinoderm larvae being major constituents.

Conclusions: The zooplankton communities in the harbour, shelf and offshore areas of Jamaica's south-east coast still show significant spatial differences; however, the zooplankton community at the offshore bank was more similar to the shelf than was expected. Such banks although located offshore, receive enrichment due to associated circulation patterns. Therefore, they should not be considered oligotrophic and based on the zooplankton community distribution would be more accurately classified as mesotrophic.
\end{abstract}

Keywords: Zooplankton; Kingston Harbour; Shelf; Offshore bank

\section{Background}

There have been several zooplankton studies conducted off the south coast of Jamaica; however, these have focused on Kingston Harbour, the Port Royal Cays area and the nearby Hellshire Coast. The studies have involved numerous stations located within and in close proximity to Kingston Harbour (Lindo 1991; Webber et al. 1996; Dunbar and Webber 2003; Persad et al. 2003;

* Correspondence: mona.webber@uwimona.edu.jm

Department of Life Sciences, University of the West Indies, Mona Campus, 4 Anguilla Close, Kingston 7, Jamaica

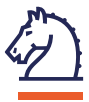

\section{Springer}

(c) 2014 Lue and Webber; licensee Springer. This is an Open Access article distributed under the terms of the Creative Commons Attribution License (http://creativecommons.org/licenses/by/2.0), which permits unrestricted use, distribution, and reproduction in any medium, provided the original work is properly credited.
Francis et al. 2013). Through these studies, Kingston Harbour has been characterized as eutrophic and as a source of enrichment for other areas of the south coast shelf. On the basis of prevailing winds and surface circulation patterns (Webber et al. 2003; Narinesingh 2007), outflow from the Harbour, mainly affects the Hellshire coastline with the Port Royal Cays area being affected only in extreme rainfall events (Webber et al. 1996). The south-east coast shelf of Jamaica and the Port Royal Cays area have therefore been classified as mesotrophic, 
receiving enrichment limited in duration and extent (Webber et al. 1996).

Studies comparing oceanic zooplankton with those of eutrophic and mesotrophic coastal areas of Jamaica are rare. In this area of the south-east coast, only one such study has been previously conducted (Moore and Sander 1979). They sampled the zooplankton and physicochemical parameters between 1962 and 1964 at four stations located in Kingston Harbour as well as in offshore, oceanic waters. Moore and Sander (1979) found an increase in the number of zooplankton species from the harbour stations (66) towards the oceanic site (87). They also observed an increase in total zooplankton abundances from offshore areas towards Kingston Harbour and attributed this to an 'island mass' effect. The island mass effect, as noted by various authors, is recognized as a general increase in biological parameters (e.g. zooplankton biomass/abundances) in the vicinity of an island, bank or land mass (Sander and Steven 1973; Sander 1981; Hernández-León 1988, 1991; Hernandez-Leon et al. 2001). This increase in the biological parameters in the vicinity of islands was found to be due to various factors such as upwelling, land run-off of nutrient-rich waters and local current dynamics which had the effect of increasing the overall productivity of waters associated with the island.

The objectives of the present study were therefore to reexamine the spatial variation in zooplankton communities across an expected eutrophication gradient, comparing the water quality of the eutrophic Kingston Harbour with mesotrophic shelf and oligotrophic oceanic waters, as was previously done 40 years ago by Moore and Sander (1979). In this study, we aim to identify zooplankton indicators for the different water masses found throughout the area (Hsieh et al. 2004) and to indicate whether there is still a gradual change in progressing from Kingston Harbour to offshore areas as is expected of the island mass effect.

\section{Methods}

\section{Field sampling}

Four stations were selected off the south-east coast of Jamaica representing areas expected to have a range of water qualities. These were therefore cited at the mouth of the eutrophic Kingston Harbour (Harbour Shoal Beacon (HSB)), the southern-most of the Port Royal Cays (South-East Cay (SEC)), near the edge of the south-east coast shelf (Windward Edge (WE)) and California Bank (CB), an offshore bank located $20 \mathrm{~km}$ away from the mouth of Kingston Harbour and surrounded by deep waters (Figure 1). Sampling was conducted at each of the four stations at approximately 2-week intervals over a 6-month period, which began in April 2004 and ended in October 2004. All stations were visited between 0830 and 1300 hours on the same day. Stations were located in areas of approximately $30 \mathrm{~m}$ depth, except for HSB where the station was $7 \mathrm{~m}$ deep.
Physicochemical variables were recorded using a Hydrolab multi-parameter probe (Loveland, CO, USA) at 5-m intervals throughout the water column for the upper $20 \mathrm{~m}$. However, due to depth at HSB, readings were taken at $1-\mathrm{m}$ intervals through the water column for $5 \mathrm{~m}$. The parameters sampled were temperature, light extinction, salinity, dissolved oxygen, oxidation reduction potential (ORP) and $\mathrm{pH}$. These were collected contemporaneously with the zooplankton samples at all stations and on all occasions.

Zooplankton sampling was conducted as replicate hauls from 20-m depths at all stations except HSB where hauls were taken from $5 \mathrm{~m}$, using plankton nets of three different mesh sizes: 64, 200 and $600 \mu \mathrm{m}$. The $600-\mu \mathrm{m}$ net had a hoop diameter of $1.0 \mathrm{~m}$, while the 200 - and $64-\mu \mathrm{m}$ nets both had hoop diameters of $0.5 \mathrm{~m}$ (UNESCO 1968). Sampling always commenced at what was believed to be the most oligotrophic site, $\mathrm{CB}$, to minimize the effects of clogging of the nets. Nets were rinsed between sites to reduce carry-over of organisms. Samples were fixed in the field with $10 \%$ formalin. The volume of water filtered by the net was calculated using the formula: Volume of water filtered $=\Pi r^{2} h$, where $h$ is the depth of the water column filtered and $r$ is the hoop radius of the plankton net.

The entire zooplankton sample was processed with taxa being identified to species (where possible), enumerated and their sample numbers converted to numbers $\mathrm{m}^{-3}$. Where necessary, sub-samples were processed, these being obtained from the parent sample using the beaker-split method (Van Guelphen et al. 1982). The sample or subsample was poured into a Bogorov tray and taxa identified to species, where possible, with the aid of a Wild M7 binocular microscope (Heerbrugg, Switzerland).

Nitrate and phosphate levels present were determined from whole water samples which were processed according to the methods outlined in Parsons et al. (1984). Illumination readings were taken with a LI-COR light meter (Fondriest Environmental, Inc., Fairborn, OH, USA) and were used to calculate extinction coefficient (EC) values for the four stations using the following equation: $\mathrm{EC}=2.3 \times\left(\log _{10} L_{1}-\log _{10} L_{2}\right) / D_{2}-D_{1}$, where $L_{1}=$ light reading at the surface (depth 1 ), $L_{2}=$ light reading at depth (depth 2), $D_{1}=$ depth 1 and $D_{2}=$ depth 2 .

\section{Community analysis}

Two community analysis tests, Jaccard community coefficient (Clifford and Stephenson 1975) and percent similarity coefficient (Kwiatkowski and Roff 1976), were applied to the zooplankton community to indicate the degree of similarity between stations. The JCC is given by the equation: $\mathrm{JCC}=[c /(a+b-c)] \times 100$, where $a$ is the number of all species occurring at one station, $b$ is the number of 


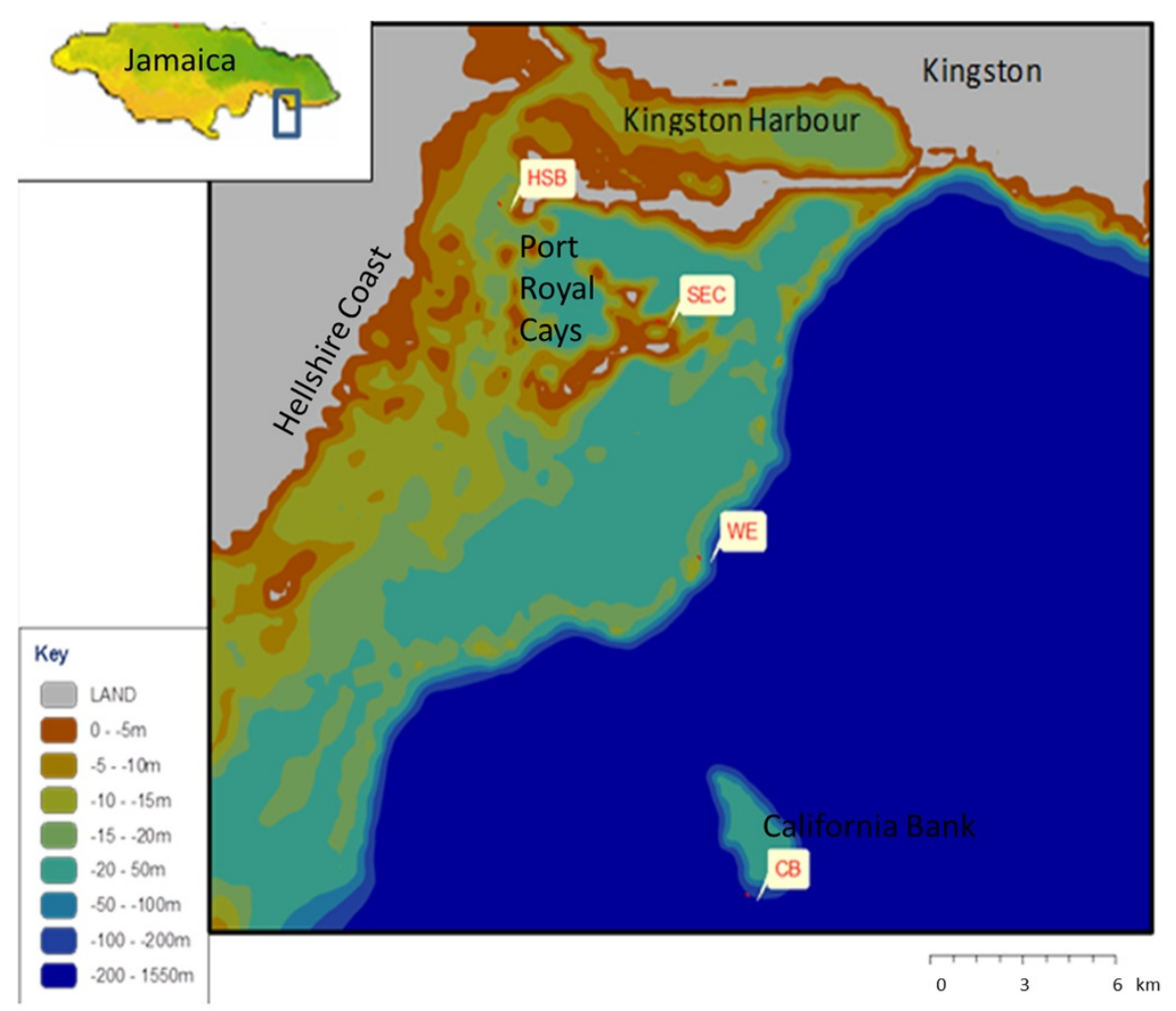

Figure 1 Map of the south-east coast shelf of Jamaica showing the four stations sampled. HSB, Harbour Shoal Beacon; SEC, South-East Cay; WE, Windward Edge; CB, California Bank.

all species occurring at the other station being compared and $c$ is the number of species common to both stations. JCC is based on the presence or absence of a species, not the number of times present or the quantity, as such single rare occurrences will carry the same weight as regular and numerically dominant species. The percent similarity coefficient (PSC) was applied using the following equation: PSC $=100-\left[0.5 \times \sum|a-b|\right]$, where $a$ and $b$ are the percentage of each species at each pair of stations.

When similarity is high, the PSC value approaches $100 \%$. PSC is biased toward the more abundant species, neglecting single rare occurrences and thus may compensate for the weakness of the Jaccard community coefficient. The results of the community coefficients were displayed as a dendrogram with stations clustered in relation to both JCC and PSC values. Finally, Shannon-Wiener index of diversity $(H)$ was determined for the zooplankton community at each station (e.g. Hsieh et al. 2004) using the following equation: $\mathrm{H}=-\sum\left[\left(p_{i}\right) \times \ln \left(p_{i}\right)\right]$, where $p_{i}=$ proportion of total sample represented by species $i$. The range for the index is normally 0 to 5 .

\section{Statistical analyses}

Multifactor analysis of variance tests (MANOVA) were applied to normally distributed or $\log _{\left(x_{+} 1\right)}$ transformed data using STATISTICA (Statsoft Inc., 1998). This test analysed the effect of one independent variable (station) on the dependent variables (physical and biological parameters) and tested whether there were significant differences between parameters at each station. The 95\% confidence interval was used and therefore differences were considered significant if the $p$ value was greater than $0.05(p>0.05)$. Pearson's product moment correlation matrix was used to show the relationship between physicochemical variables and the zooplankton community (Hwang et al. 2010).

\section{Results}

\section{Physicochemical parameters}

The physiochemical data for each station represented the mean of values taken through the water column as this was the path through which the zooplankton net was hauled. There was no significant temporal variation or evidence of seasonality in these parameters and so the means of fortnightly collections are presented for each station. Eleven physicochemical parameters were investigated, of which nine showed significant variation between stations (Table 1).

The physicochemical parameters that varied significantly between stations did not all show the expected 
Table 1 All physicochemical and biological variables examined during the study

\begin{tabular}{|c|c|c|c|c|c|c|}
\hline \multirow[t]{2}{*}{ Variable } & \multirow{2}{*}{$\begin{array}{l}\text { ANOVA significance } \\
\text { value (95\%) }\end{array}$} & \multirow[t]{2}{*}{ Number } & \multicolumn{4}{|c|}{ Means at each station with standard error } \\
\hline & & & HSB & SEC & WE & CB \\
\hline \multicolumn{7}{|l|}{ Physicochemical variables (water quality) } \\
\hline Temperature $\left({ }^{\circ} \mathrm{C}\right)$ & $<0.001$ & 108 & $29.63 \pm 0.29$ & $29.01 \pm 0.29$ & $27.82 \pm 0.32$ & $28.79 \pm 0.35$ \\
\hline Salinity (\%o) & $<0.001$ & 108 & $36.10 \pm 0.08$ & $36.18 \pm 0.05$ & $36.21 \pm 0.03$ & $36.20 \pm 0.04$ \\
\hline $\mathrm{DO}\left(\mathrm{mg} \mathrm{I}^{-1}\right)$ & $<0.001$ & 108 & $4.55 \pm 0.04$ & $4.44 \pm 0.09$ & $5.14 \pm 0.14$ & $5.14 \pm 0.09$ \\
\hline $\mathrm{pH}$ (pH units) & $<0.001$ & 107 & $8.27 \pm 0.01$ & $8.24 \pm 0.01$ & $8.24 \pm 0.01$ & $8.17 \pm 0.01$ \\
\hline Specific conductivity $\left(\mathrm{mS} \mathrm{cm}^{-1}\right)$ & $<0.001$ & 108 & $53.94 \pm 0.11$ & $54.51 \pm 0.08$ & $54.14 \pm 0.04$ & $54.51 \pm 0.07$ \\
\hline TDS (ppm) & $<0.001$ & 108 & $34.54 \pm 0.07$ & $34.89 \pm 0.05$ & $34.89 \pm 0.04$ & $34.92 \pm 0.04$ \\
\hline $\log _{(x+1)}$ extinction coefficient & 0.031 & 41 & $0.53 \pm 0.16$ & $0.07 \pm 0.01$ & $0.05 \pm 0.01$ & $0.04 \pm 0.01$ \\
\hline $\log _{(x+1)}$ turbidity $\left(\mathrm{NTU} / \mathrm{mg} \mathrm{I}^{-1}\right)$ & 0.164 & 108 & $0.87 \pm 0.11$ & $0.64 \pm 0.12$ & $0.80 \pm 0.21$ & $0.14 \pm 0.02$ \\
\hline $\log _{(x+1)} \operatorname{ORP}(m V)$ & 0.011 & 108 & $518 \pm 4.91$ & $532 \pm 8.80$ & $552 \pm 7.39$ & $605 \pm 10.43$ \\
\hline Nitrates $\left(\mu \mathrm{g}\right.$ at $\left.I^{-1}\right)$ & 0.079 & 108 & $0.34 \pm 0.11$ & $0.31 \pm 0.10$ & $0.22 \pm 0.06$ & $0.32 \pm 0.09$ \\
\hline Phosphates ( $\mu \mathrm{g}$ at $\mathrm{I}^{-1}$ ) & 0.027 & 108 & $0.09 \pm 0.02$ & $0.08 \pm 0.01$ & $0.05 \pm 0.01$ & $0.07 \pm 0.01$ \\
\hline Total chlorophyll a $\left(\mu \mathrm{g} \mathrm{I}^{-1}\right)$ & $<0.001$ & 108 & $1.001 \pm 0.15$ & $0.262 \pm 0.02$ & $0.127 \pm 0.01$ & $0.081 \pm 0.01$ \\
\hline \multicolumn{7}{|l|}{ Biological variables (zooplankton) } \\
\hline Mean number of species & $<0.001$ & 41 & $53 \pm 1.5$ & $70 \pm 1.9$ & $71 \pm 1.6$ & $68 \pm 1.7$ \\
\hline Total abundance (numbers $\mathrm{m}^{-3}$ ) & $<0.001$ & 41 & $5,963 \pm 398$ & $2,251 \pm 193$ & $2,491 \pm 240$ & $2,150 \pm 122$ \\
\hline Calanoida (numbers $\mathrm{m}^{-3}$ ) & $<0.001$ & 41 & $1,497 \pm 299$ & $587 \pm 80$ & $568 \pm 104$ & $338 \pm 22$ \\
\hline Cyclopoid (numbers $\mathrm{m}^{-3}$ ) & $<0.001$ & 41 & $375 \pm 61$ & $303 \pm 30$ & $349 \pm 80$ & $275 \pm 24$ \\
\hline Harpacticoid (numbers $\mathrm{m}^{-3}$ ) & $<0.001$ & 41 & $33 \pm 11$ & $19 \pm 9$ & $50 \pm 11$ & $44 \pm 7$ \\
\hline Larvae (numbers $\mathrm{m}^{-3}$ ) & $<0.001$ & 41 & $2,428 \pm 411$ & $930 \pm 136$ & $1,058 \pm 218$ & $1,480 \pm 115$ \\
\hline Decapod (numbers $\mathrm{m}^{-3}$ ) & $<0.001$ & 41 & $102 \pm 21$ & $13 \pm 1$ & $2 \pm .4$ & $8 \pm 2$ \\
\hline $\log _{(x+1)}$ Cladocera (numbers $\mathrm{m}^{-3}$ ) & $<0.001$ & 41 & $289 \pm 81$ & $5 \pm 2$ & $13 \pm 7$ & $5 \pm 1$ \\
\hline $\log _{(x+1)}$ Cnidaria (numbers $\mathrm{m}^{-3}$ ) & $<0.001$ & 41 & $117 \pm 31$ & $30 \pm 11$ & $17 \pm 3$ & $32 \pm 5$ \\
\hline $\log _{(x+1)}$ Larvacea (numbers $\mathrm{m}^{-3}$ ) & 0.418 & 41 & $566 \pm 220$ & $607 \pm 143$ & $436 \pm 226$ & $225 \pm 33$ \\
\hline $\log _{(x+1)}$ Mollusc (numbers $\mathrm{m}^{-3}$ ) & 0.095 & 41 & $177 \pm 30$ & $140 \pm 24$ & $120 \pm 16$ & $57 \pm 13$ \\
\hline Chaetognath (numbers $\mathrm{m}^{-3}$ ) & 0.389 & 41 & $56 \pm 12$ & $47 \pm 6$ & $41 \pm 7$ & $33 \pm 8$ \\
\hline
\end{tabular}

Means with standard error values are also given for each station. HSB, Harbour shoal beacon; SEC, South-East cay; WE, Windward edge; CB, California bank.

trend of gradual change with distance from the HSB to CB. Only ORP (Figure 2) showed gradual change with increasing distance offshore. Extinction coefficient and total chlorophyll $a$ (Small et al. 2013) had a similar pattern with the highest mean values at HSB, but this was followed by a sharp decline at SEC and the stations further offshore. For most other physicochemical parameters, there was no clear pattern, and in some cases (e.g. phosphates, Figure 3), $\mathrm{CB}$, located furthest offshore, often had mean values that were higher than WE or SEC, located on the shelf.

\section{Zooplankton parameters}

Several numeric indices were used to describe the variability in the zooplankton across stations, which include the following: number of species/taxa, mean total abundance and mean abundance of major groups and individual species. Ten zooplankton parameters were tested for significant spatial variability, and seven were found to vary significantly between stations (Table 1 ).

\section{Taxonomic richness and diversity}

One hundred forty-seven different taxa of zooplankton were identified during the study (Table 2), which is $22 \%$ more than the 114 taxa found by Moore and Sander (1979). As expected, the Copepoda was the most diverse group (76 species) of which the order Calanoida (37 species) was the most dominant. The rare order Monstrilloida was represented by one species. The group comprising larval stages was also very diverse with representatives from most taxonomic groups, including copepods. Although zooplankton organisms were identified to the species where possible ( $c f$. 'Methods' section), the members of the group 'larvae', which were not easily identified to species, were represented as orders. 


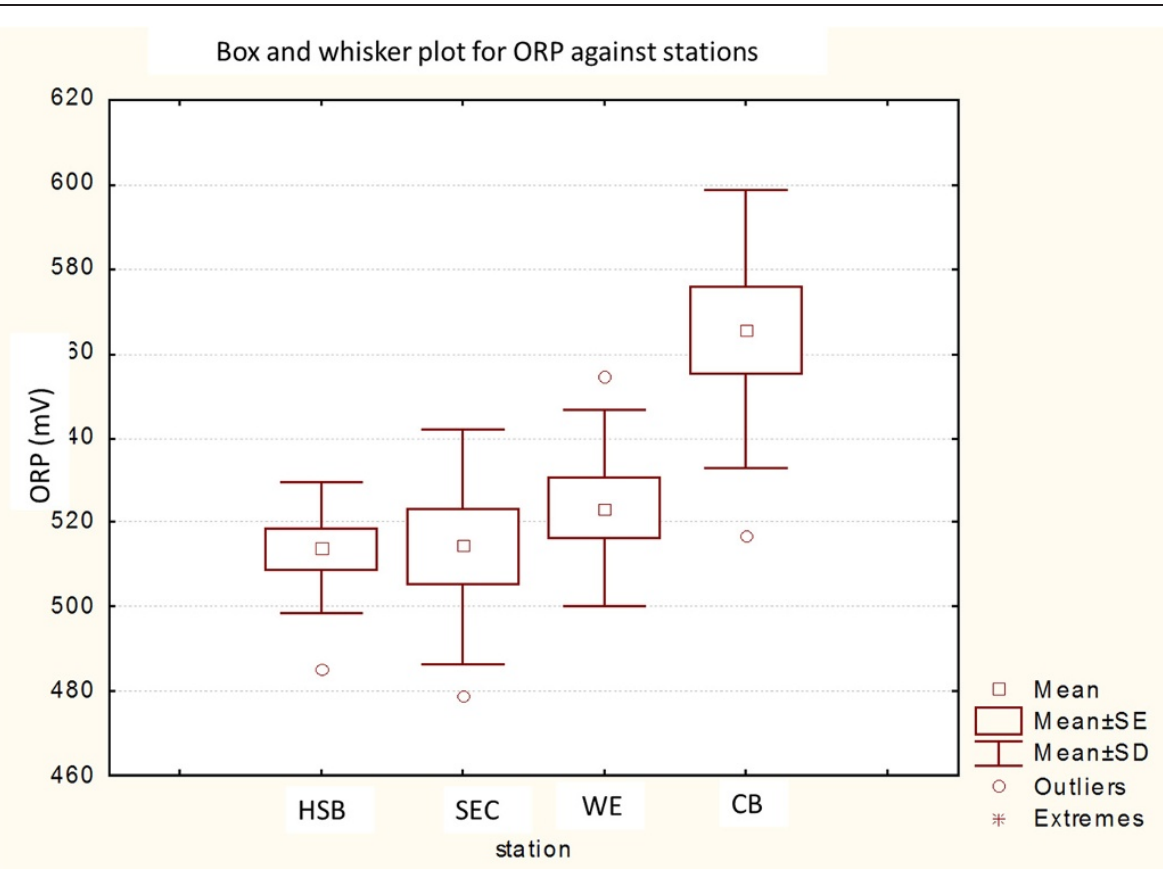

Figure 2 Box and whisker plot for ORP at the four stations. HSB, Harbour Shoal Beacon; SEC, South-East Cay; WE, Windward Edge; CB, California Bank.

When stations were compared, HSB had the lowest total number of species (taxonomic richness) with 81. SEC with 106 different taxa and WE with 114 had the greatest total taxonomic richness. The furthest station from the island shelf, $\mathrm{CB}$, had 94 different taxa (Table 3). The mean values for the number of species or taxa for the sampling period varied significantly (MANOVA, $p<0.001$ ) between stations (Figure 4). Shannon-Weiner diversity index values (Table 2) followed a somewhat similar trend to richness, but with CB having the lowest diversity (2.61) which was

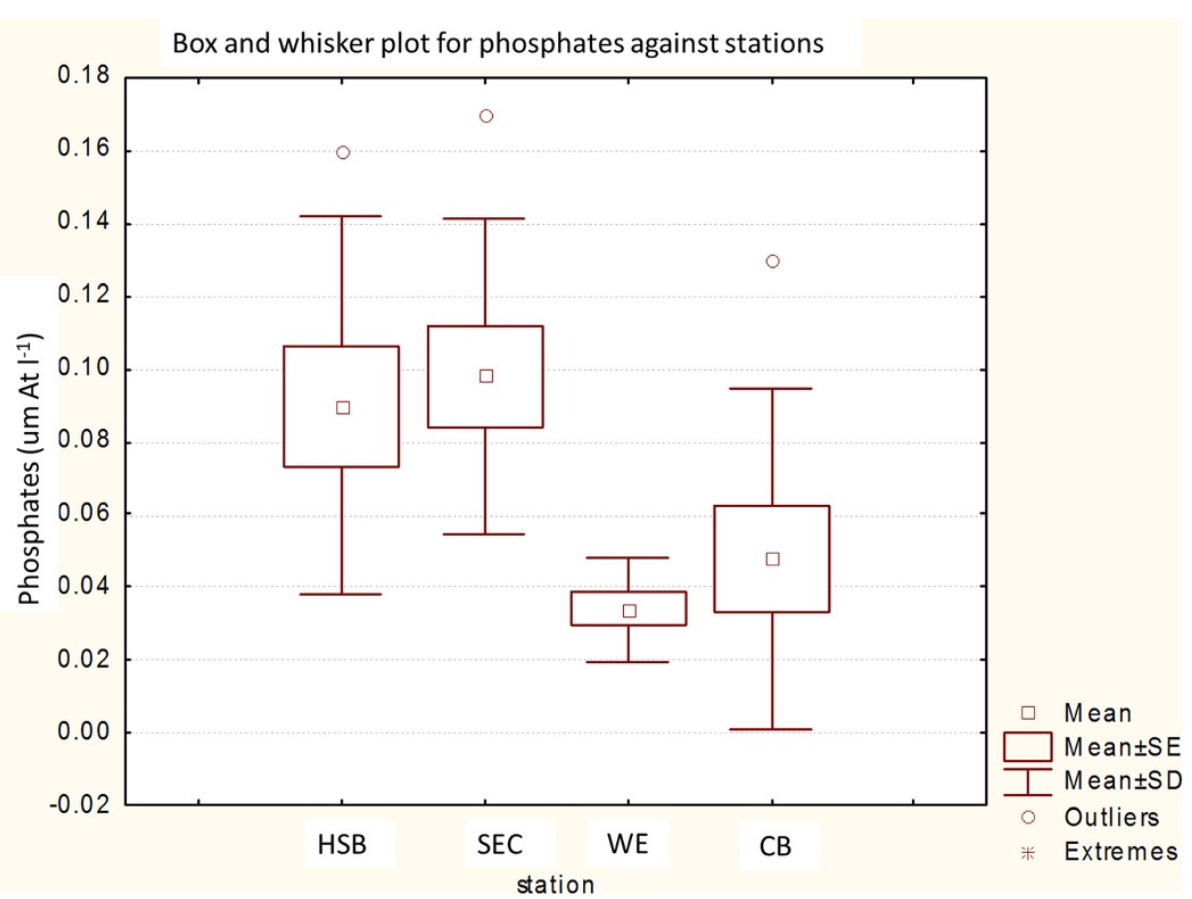

Figure 3 Box and whisker plot for phosphates at the four stations. HSB, Harbour Shoal Beacon; SEC, South-East Cay; WE, Windward Edge; $\mathrm{CB}$, California Bank. 
Table 2 Zooplankton species list, percentage occurrence of each species and Simpson's diversity index for each station

\begin{tabular}{lllll}
\hline Taxa & HSB & SEC & WE & CB \\
\hline
\end{tabular}

Cnidaria

Abylopsis spp.

Aglama sp.

Aglaura spp.

Clytia sp.

Cordagalma sp.

Ephysra aurata

Eudoxid sp.

Euphysora gracilis

Eutima sp.

Liriope tetraphylla

Loadicea pulchra

Muggiea sp.

Obelia sp.

Phialopsis diegensis

Phialucium sp.

Solamaris sp.

Solmunella sp.

Steenstrupia sp

Ctenophora

Beroe sp.

Cladocera

Penilia avirostris

Evadne tergestina

Chaetognatha

Eukhronia proboscidea
Eukhronia bathypelagica
Khronitta subtilis
Sagitta bipunctata
Sagitta decipens
Sagitta enflata
Sagitta hispida
Sagitta megalophthalma
Sagitta serratodentata
Sagitta tenuis
Pterosagitta draco
Amphipoda
Amphipod
Hyperia sp.

Calanoida

$$
\text { Acartia lilljeborji }
$$

Acartia spinata

$\begin{array}{cccc} & 30 & 50 & 60 \\ 20 & 40 & 80 & 60 \\ 10 & 40 & 90 & 90 \\ 20 & & & \\ & & 20 & 10 \\ & & & 10 \\ & 80 & 80 & 100 \\ & & 10 & 10 \\ 10 & & 10 & \\ 100 & 40 & & \\ 70 & & 20 & \\ & 50 & 70 & 80 \\ 60 & 30 & 30 & 10 \\ & & 10 & 10 \\ 10 & & & \\ 90 & & & \\ 10 & 10 & & \\ 10 & 40 & 30 & \end{array}$

10

10

$\begin{array}{llll}100 & 40 & 30 & 20 \\ 40 & 30 & 70 & 70\end{array}$

10

10

$30 \quad 20$

10

$20 \quad 10$

$100 \quad 100 \quad 100$

$80 \quad 70 \quad 70$

$70 \quad 10$

$10 \quad 10$

10

20

20

$30 \quad 20$

40

10

50
Table 2 Zooplankton species list, percentage occurrence of each species and Simpson's diversity index for each station (Continued)

\begin{tabular}{|c|c|c|c|c|}
\hline Acartia tonsa & 80 & 50 & & 10 \\
\hline Acrocalanus sp. & 10 & 70 & 70 & 90 \\
\hline Aetidus sp. & & 10 & & \\
\hline Calocalanus spp. & & 10 & 60 & 90 \\
\hline Calocalanus pavo & 30 & 80 & 100 & 70 \\
\hline Calocalanus pavoninus & & 40 & 60 & 40 \\
\hline Calanopia americana & 10 & 30 & 10 & 10 \\
\hline Candacia bipinnata & 10 & & 20 & \\
\hline Candacia bispinosa & & & 10 & \\
\hline Candacia curta & & 20 & 10 & \\
\hline Candacia longimana & & 20 & & \\
\hline Candacia pachydactyla & 10 & 20 & 50 & 60 \\
\hline Candacia paenelongimana & 10 & & & \\
\hline Candacia varicans & & 10 & 10 & \\
\hline Centropages bradyi & & & & 10 \\
\hline Centropages velificatus & 100 & 100 & 40 & 20 \\
\hline Centropages violaceous & 10 & 20 & & 40 \\
\hline Clausocalanus sp. & & 90 & 80 & 10 \\
\hline Euaugaptilus nodifrons & & & 10 & \\
\hline Eucalanus sp. & & 10 & 10 & 20 \\
\hline Eucalanus micronatus & & & & 60 \\
\hline Eucalanus subtenuis & & & & 10 \\
\hline Eucheata marina & & 60 & 40 & 100 \\
\hline Eutima sp. & 10 & & 10 & \\
\hline Labidocera aestiva & & 10 & & \\
\hline Labidocera nerri & & 10 & 10 & \\
\hline Mecynocera sp. & & & 10 & 50 \\
\hline Neocalanus robustior & & & & 20 \\
\hline Paracandacia bispinosa & & & 10 & \\
\hline Paracalanus sp. & 80 & 100 & 90 & 70 \\
\hline Paracalanus aculeatus & 20 & & 20 & 30 \\
\hline Paracalanus parvus & 100 & 50 & 30 & 60 \\
\hline Paraeucalanus sp. & & & 20 & \\
\hline Pontella mimocerami & & 10 & 10 & \\
\hline Pontellina sp. & & 10 & 30 & \\
\hline Rhincalanus cornutus & & & 10 & \\
\hline Scolecithrix sp. & 10 & 20 & 60 & 70 \\
\hline Subeucalanus mucronatus & & 10 & 30 & \\
\hline Subeucalanus pileatus & 30 & & & \\
\hline Subeucalanus subcrassus & 30 & 30 & 10 & 10 \\
\hline Temora longicornis & 70 & & 20 & \\
\hline Temora stylifera & 20 & 60 & 50 & 20 \\
\hline Temora turbinata & 10 & 50 & 10 & \\
\hline
\end{tabular}


Table 2 Zooplankton species list, percentage occurrence of each species and Simpson's diversity index for each station (Continued)

\begin{tabular}{|c|c|c|c|c|}
\hline Undinula vulgaris & 80 & 90 & 100 & 100 \\
\hline \multicolumn{5}{|l|}{ Cyclopoida } \\
\hline Copilia sp. & & 40 & 50 & 60 \\
\hline Corycaeus carinata & & & 10 & 10 \\
\hline Coryceaus catus & 40 & 40 & 50 & 40 \\
\hline Corycaeus clause & & & 40 & 30 \\
\hline Corycaeus latus & & 10 & 10 & 20 \\
\hline Corycaeus lautus & & 30 & 60 & 70 \\
\hline Corycaeus limbatus & & & 20 & 10 \\
\hline Corycaeus speciosus & 100 & 90 & 100 & 90 \\
\hline Corycaeus typicus & & & 10 & \\
\hline Dioithona occulata & 30 & 10 & & 20 \\
\hline Farranula carinata & & 50 & 100 & 100 \\
\hline Farranula gracilis & 70 & 70 & 70 & 60 \\
\hline Farranula rostrata & 40 & 100 & 100 & 50 \\
\hline Lubbocika sp. & 10 & 10 & 20 & 10 \\
\hline Oithona hebes & & & 80 & \\
\hline Oithona nana & 90 & 100 & 70 & 40 \\
\hline Oithona similis & & 10 & 10 & \\
\hline Oithona plumifera & 60 & 90 & 60 & 50 \\
\hline Oncea meditteranea & 10 & 10 & 50 & 30 \\
\hline Oncea media & & 10 & 10 & \\
\hline Sagitella sp. & & 10 & & \\
\hline Saphirella tropica & 10 & 50 & 10 & \\
\hline Sapphirina spp. & 10 & 10 & 10 & 50 \\
\hline \multicolumn{5}{|l|}{ Harpacticoida } \\
\hline Clytemnestra sp. & 10 & 10 & 30 & 20 \\
\hline Euterpina acutifrons & 80 & 50 & 40 & 30 \\
\hline Macrosetella gracilis & & 20 & 40 & 60 \\
\hline Microsetella norvegica & 30 & 70 & 90 & 100 \\
\hline Miracia efferata & 40 & 20 & 20 & 30 \\
\hline Oculosetella sp. & & 20 & & \\
\hline \multicolumn{5}{|l|}{ Monstrilloida } \\
\hline Monstrilla sp. & 10 & 20 & & \\
\hline \multicolumn{5}{|l|}{ Decapoda } \\
\hline Decapod (unidentified) & 60 & 80 & 40 & 20 \\
\hline Lucifer faxoni & 100 & 60 & 30 & 20 \\
\hline \multicolumn{5}{|l|}{ Larvacea } \\
\hline Oikopleura dioca & 100 & 100 & 100 & 100 \\
\hline Fritillaria sp. & 40 & 100 & 80 & 90 \\
\hline \multicolumn{5}{|l|}{ Pteropoda } \\
\hline Creseis acicula & 70 & 100 & 80 & 30 \\
\hline Diacria sp. & & 10 & & 20 \\
\hline
\end{tabular}

Table 2 Zooplankton species list, percentage occurrence of each species and Simpson's diversity index for each station (Continued)

\begin{tabular}{|c|c|c|c|c|}
\hline \multicolumn{5}{|l|}{ Thaliacea } \\
\hline Doliolum sp. & 10 & 20 & 20 & 30 \\
\hline Thalia sp. & 20 & 20 & 60 & 70 \\
\hline \multicolumn{5}{|l|}{ Larvae } \\
\hline Actinula & & 20 & 10 & \\
\hline Auricularia & 20 & 80 & 60 & 70 \\
\hline Bipinnaria larva of starfish & 10 & 60 & 70 & 90 \\
\hline Copepodites & 90 & 100 & 100 & 100 \\
\hline Copepod nauplii & 100 & 100 & 90 & 100 \\
\hline Cirripede & 10 & 10 & 30 & \\
\hline Euphausid & 10 & 20 & 60 & 90 \\
\hline Echinocardium cordatum & & & 10 & 20 \\
\hline Echinopluteus larvae & 60 & 60 & 80 & 60 \\
\hline Fish eggs & 20 & 70 & 90 & 100 \\
\hline Fish larvae & 20 & 70 & 60 & 50 \\
\hline Gastropod larva & 70 & 100 & 100 & 100 \\
\hline Heteropod larvae & 50 & 10 & 40 & \\
\hline Lanice larvae & & 40 & & 20 \\
\hline Ophiopluteus larvae & 10 & 60 & 80 & 70 \\
\hline Pontellid nauplius & & 30 & 60 & 10 \\
\hline Phylossoma larvae & 10 & 30 & 10 & \\
\hline Polychaete spp. & 50 & 90 & 90 & 80 \\
\hline Porcellanid larvae & 60 & 40 & 10 & 40 \\
\hline Sagitta juvenile & 10 & & 40 & 30 \\
\hline Sergestid & & & 10 & \\
\hline Spionid larvae & & 90 & 40 & 30 \\
\hline Stomatopod larvae & 20 & 10 & 10 & \\
\hline Tomopteris sp. & 10 & 10 & 20 & 20 \\
\hline Zoea & 50 & 80 & 90 & 90 \\
\hline Number of species (richness) & 81 & 106 & 114 & 94 \\
\hline Shannon-Weiner index & 2.63 & 2.68 & 3.66 & 2.61 \\
\hline
\end{tabular}

similar to HSB (2.63). WE therefore had the highest diversity value (3.66) as well as the highest taxonomic richness.

The percentage occurrence determined for each taxon at each station (Table 2) facilitated the identification of potential indicators. Only two species (Sagitta enflata and Oikopleura dioca) showed 100\% occurrence at all four stations, while most other taxa, if found at all four stations, showed varying percentage occurrence. The Cnidaria and Ctenophora tended to have greatest occurrence at offshore areas, except for Liriope tetraphylla which was found at HSB on all sampling occasions. Organisms and groups which displayed dominance in both 
Table 3 Zooplankton taxa with potential for use as indicators of water masses

\begin{tabular}{lcccc}
\hline \multirow{2}{*}{ Taxa } & \multicolumn{4}{c}{ Mean numbers $\mathbf{~}^{\mathbf{- 3}}$ with standard error } \\
\cline { 2 - 5 } & HSB & SEC & WE & CB \\
\hline Evadne tergestina & $10.3 \pm 5.6$ & $0.5 \pm 0.4$ & $2.9 \pm 1.9$ & $4.4 \pm 1.9$ \\
Penilia avirostris & $278.4 \pm 77.1$ & $3.9 \pm 2.2$ & $10.3 \pm 8.1$ & $0.3 \pm 0.2$ \\
Sagitta enflata & $45.6 \pm 10.1$ & $36.7 \pm 5.3$ & $34.2 \pm 5.2$ & $29.0 \pm 7.6$ \\
Clausocalanus sp. & 0 & $45.3 \pm 18.3$ & $154.1 \pm 42.4$ & $9.9 \pm 9.9$ \\
Paracalanus parvus & $734.6 \pm 222.4$ & $88.9 \pm 18.1$ & $48.9 \pm 32.4$ & $73.8 \pm 21.4$ \\
Undinula vulgaris & $19.1 \pm 8.1$ & $87.1 \pm 26.5$ & $40.6 \pm 7.3$ & $85.2 \pm 23.4$ \\
Farranula carinata & 0 & $4.8 \pm 2.0$ & $34.1 \pm 9.7$ & $40.4 \pm 12.1$ \\
Oithona nana & $192.5 \pm 42.9$ & $119.7 \pm 15.4$ & $6.3 \pm 1.7$ & $5.9 \pm 2.7$ \\
Microsetella norvegica & $4.3 \pm 2.7$ & $9.4 \pm 2.7$ & $30.7 \pm 6.1$ & $37.2 \pm 5.6$ \\
Lucifer faxoni & $23.9 \pm 7.4$ & $0.6 \pm 0.2$ & $0.4 \pm 0.2$ & $2.8 \pm 2.1$
\end{tabular}

$\mathrm{HSB}$, Harbour shoal beacon; SEC, South-East cay; WE, Windward edge; $\mathrm{CB}$, California bank.

abundance and percentage occurrence at particular stations and which showed significant spatial variation (MANOVA, $p \leq 0.001$ ) were identified as potential indicators. These taxa were as follows: Penilia avirostris, Clausocalanus sp., Paracalanus parvus, Undinula vulgaris, Farranula carinata, Oithona nana, Microsetella norvegica and Lucifer faxoni.

Penilia avirostris, which was a previously described Kingston Harbour indicator (Grahame 1976), was always found at HSB and showed decreasing percentage occurrence and abundance with distance from the Harbour; however, there was no pattern of gradual decline. L. faxoni, also previously identified as a Kingston Harbour indicator (Lindo 1991), showed the greatest percentage occurrence and abundance near the Harbour but again lacked the pattern of decline with increasing distance offshore. M. norvegica showed the opposite pattern with the lowest percentage occurrence and abundance at $\mathrm{HSB}$, highest at CB and gradual increase with increasing distance offshore (Figure 5). F. carinata was similar to $M$. norvegica (Figure 6) and showed a gradual increase from zero at HSB to the highest mean abundances at station $\mathrm{CB}$.

\section{Total zooplankton abundances}

Overall greatest total abundances (numbers $\mathrm{m}^{-3}$ ) were obtained at station HSB which had a mean value of 5,963 individuals $\mathrm{m}^{-3}$, while stations SEC, WE and CB had similar mean values of just over 2,000 individuals $\mathrm{m}^{-3}$ (Figure 7). Larvae were the most abundant fraction at three of the four stations and accounted for more than half of the total zooplankton abundance at California Bank. The group 'larvae' was dominated by copepod nauplii, fish eggs and echinoderm larval stages. Copepods made the second largest contribution to the overall abundances but exceeded the larvae only at WE.

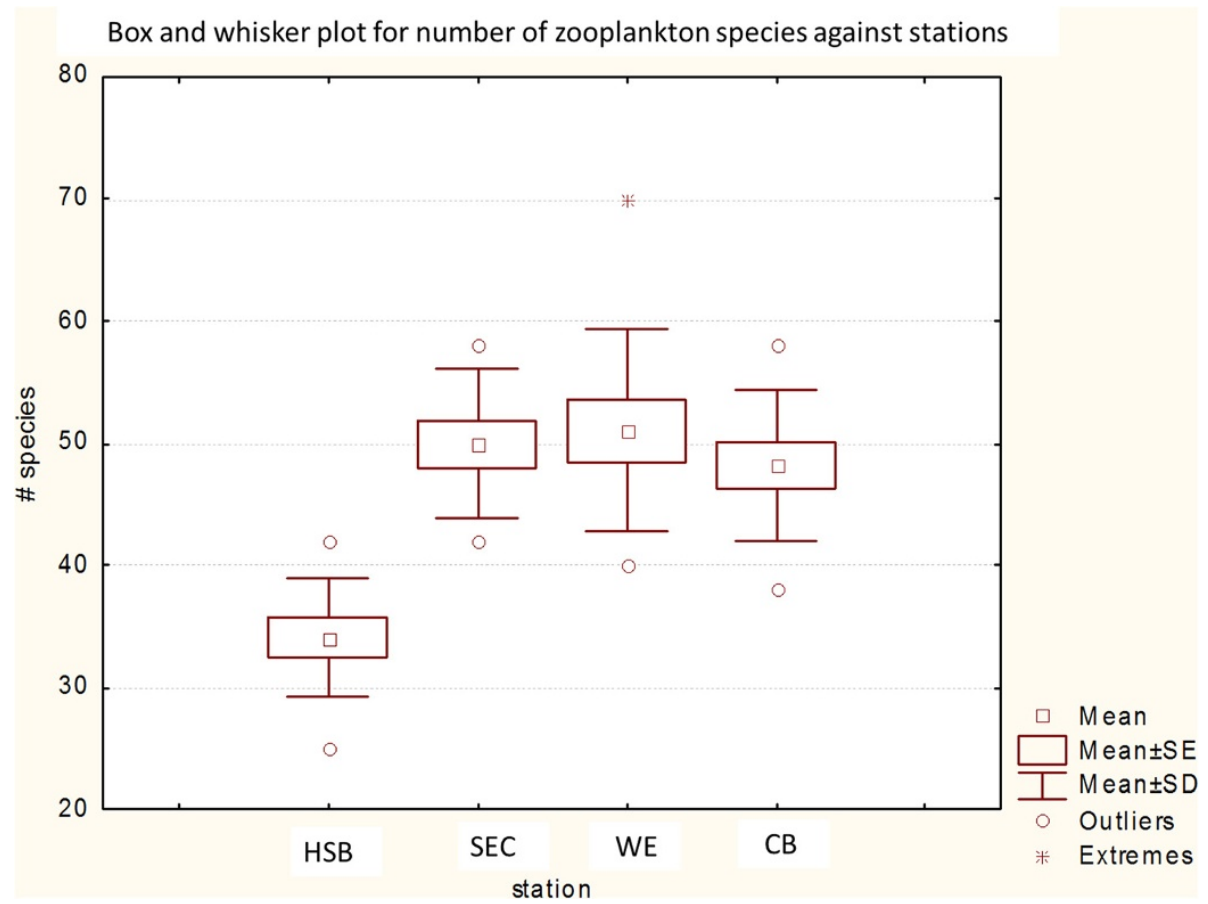

Figure 4 Box and whisker plot for number of zooplankton species at the four stations. HSB, Harbour Shoal Beacon; SEC, South-East Cay; WE, Windward Edge; $C B$, California Bank. 


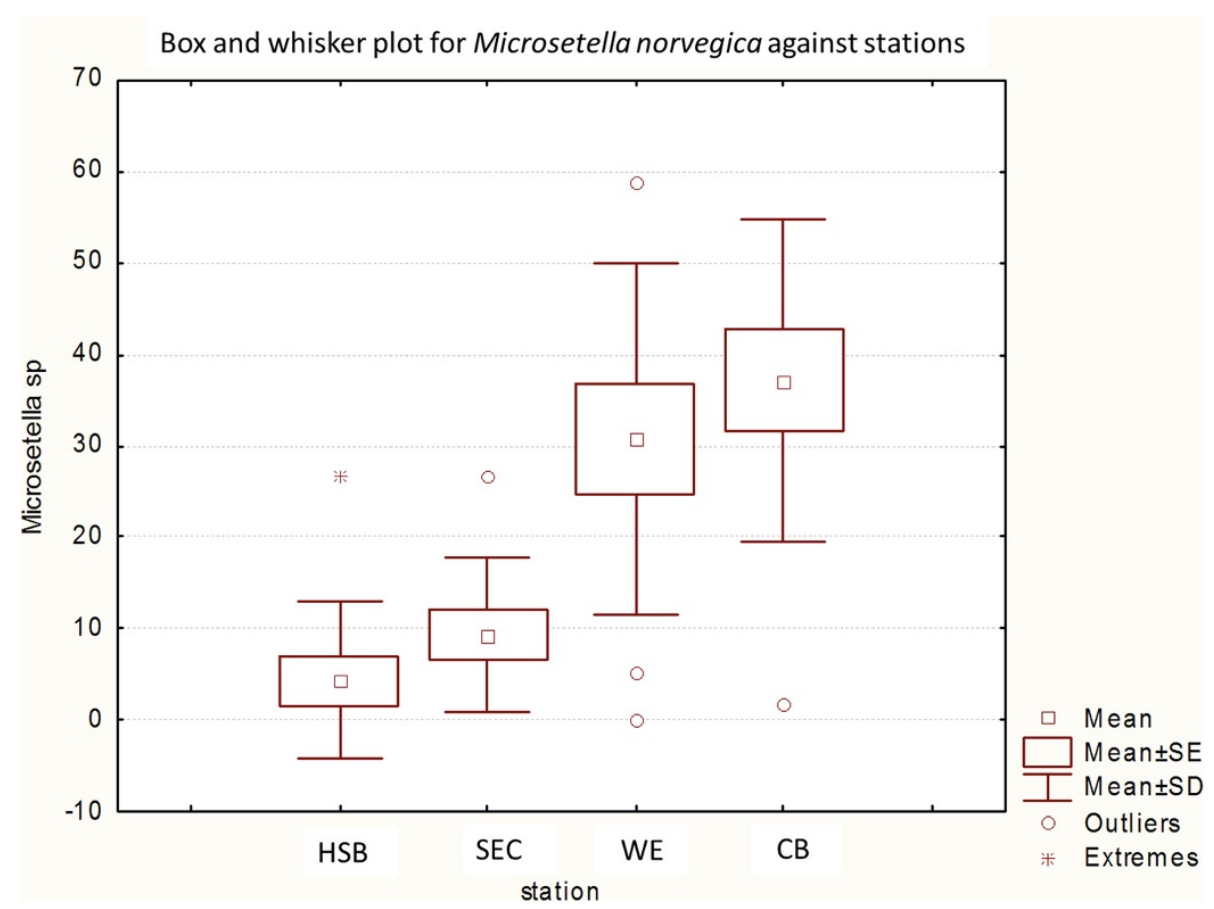

Figure 5 Box and whisker plot forMicrosetella norvegicaat the four stations. HSB, Harbour Shoal Beacon; SEC, South-East Cay; WE, Windward Edge; CB, California Bank.

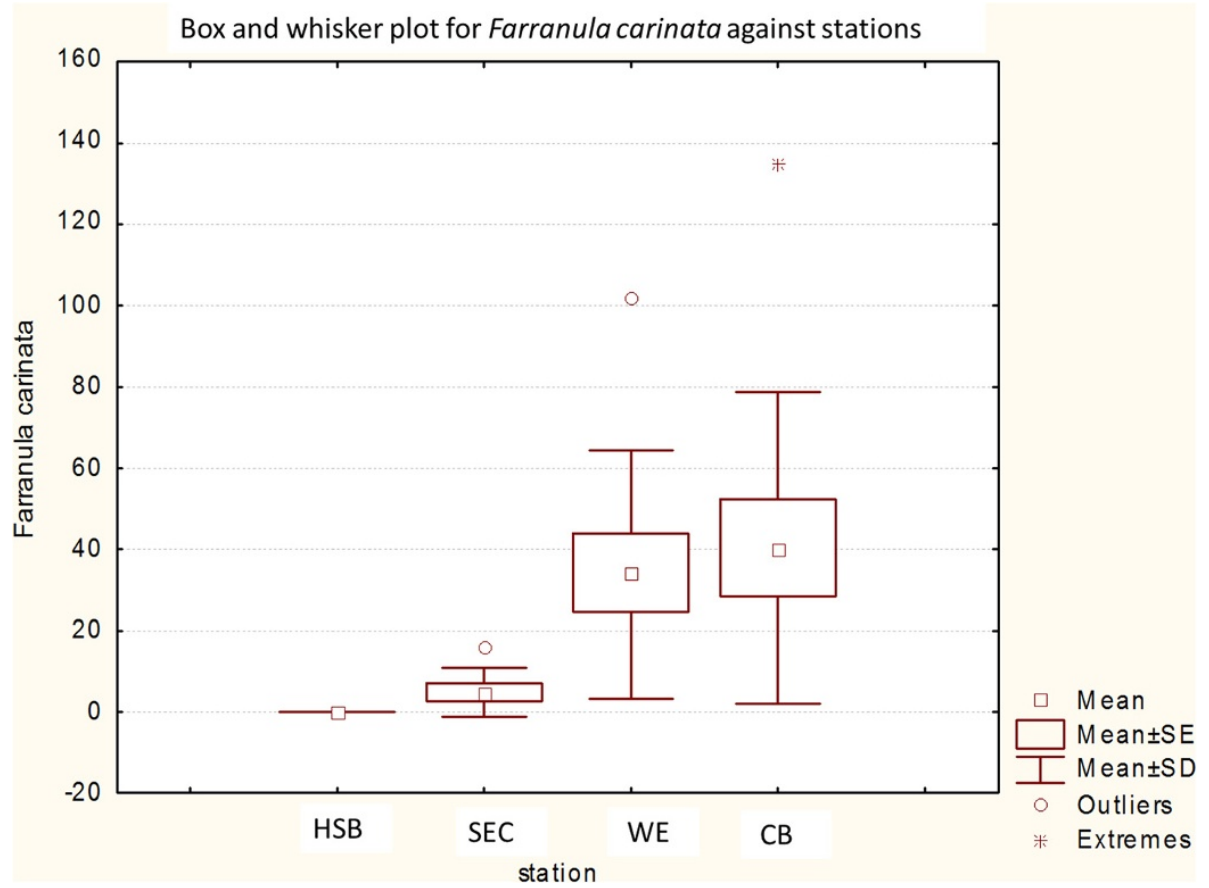

Figure 6 Box and whisker plot forFarranula carinataat the four stations. HSB, Harbour Shoal Beacon; SEC, South-East Cay; WE, Windward Edge; CB, California Bank. 


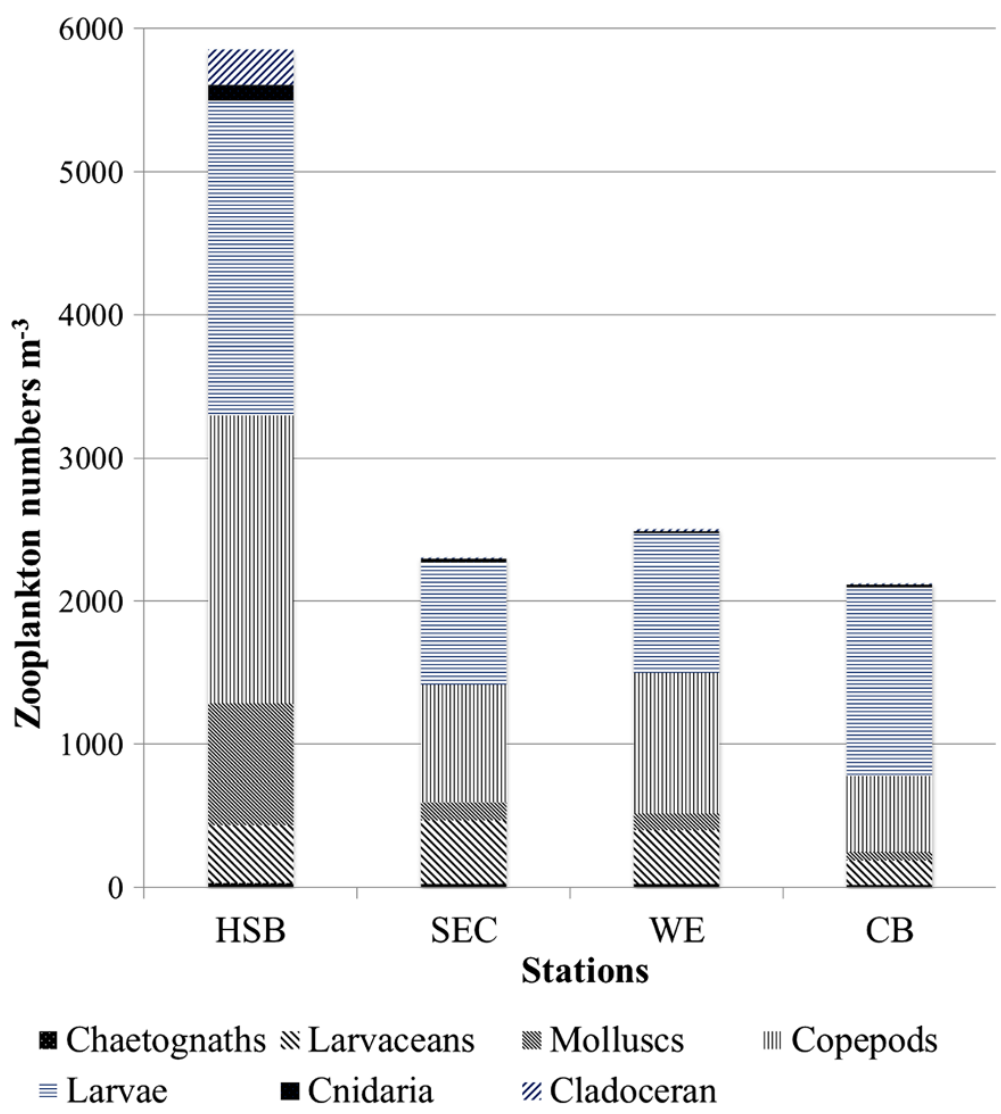

Figure 7 Mean abundances of the major zooplankton taxonomic groups found at each station. HSB, Harbour Shoal Beacon; SEC, South-East Cay; WE; Windward Edge; CB, California Bank.

\section{Correlation analysis}

Physicochemical parameters were correlated with the biological and size-fractionated phytoplankton biomass from a concurrent study (Small et al. 2013). The resultant correlation matrix (Table 4) indicated that specific conductivity and total dissolved solids showed a strong correlation with the biological variables. The phytoplankton size classes also correlated strongly with the number of species and total abundance of zooplankton.

\section{Community coefficients}

The cluster analysis dendrograms generated using the community coefficients JCC and PSC both showed two general groups of stations based on the zooplankton community, one with station HSB as the sole member and the other with the remaining three stations (Figure 8A,B). JCC, however, showed this trend of general increase in community similarity from stations $\mathrm{HSB}$ to $\mathrm{CB}$, and station HSB had the least similar communities compared to the other stations with values all less than $38 \%$ (JCC < 0.38). The highest similarity $(66 \%)$ was seen between stations CB and WE with a JCC value of 0.66 . Stations SEC and WE were also found to be quite similar with an index of 0.63 . PSC values were all higher ( $>53 \%)$, but HSB still had overall lowest similarity compared to other stations (Table 5) with only SEC being $60 \%$ similar.

\section{Discussion}

The zooplankton communities of Jamaica's bays and harbors have been studied extensively for use in water quality monitoring as well as to indicate the influence of different water masses (Grahame 1976; Lindo 1991; Dunbar and Webber 2003; Webber et al. 2005; Campbell et al. 2008). However, only Moore and Sander (1979) previously made direct comparison between inshore stations and those beyond the coastal shelf. Webber and Roff (1995) conducted an intensive study of plankton and water quality offshore Discovery Bay, north coast of Jamaica, but this was facilitated by the coastal shelf of Jamaica's north coast being narrow (maximum of $1.6 \mathrm{~km}$ wide) compared to the south coast where the shelf has a maximum width of $24 \mathrm{~km}$ (Aiken and Kong 2000).

With the relatively large distances between the stations of this study and their linear arrangement, the expectation was that significant spatial differences would be obtained for all parameters and that values would gradually increase or decrease with increasing distance 
Table 4 Correlation matrix relating physicochemical and biological parameters found to be significantly different across stations

\begin{tabular}{|c|c|c|c|c|c|c|c|c|c|c|c|c|c|c|c|c|c|c|c|c|}
\hline Variable & Station & Distance & Temperature & Salinity & DO & $\mathrm{pH}$ & $\begin{array}{l}\text { Specific } \\
\text { conductivity }\end{array}$ & TDS & ORP & Phosphorus & $\begin{array}{l}\text { Number } \\
\text { of species }\end{array}$ & Abundance & Calanoida & Cladocera & Larvae & Cnidaria & Decapoda & Net & Nano & Pico \\
\hline Station & 1 & & & & & & & & & & & & & & & & & & & \\
\hline Distance & 0.99 & 1 & & & & & & & & & & & & & & & & & & \\
\hline Temperature & -0.35 & -0.35 & 1 & & & & & & & & & & & & & & & & & \\
\hline Salinity & 0.62 & 0.57 & -0.05 & 1 & & & & & & & & & & & & & & & & \\
\hline DO & 0.37 & 0.37 & -0.49 & 0.21 & 1 & & & & & & & & & & & & & & & \\
\hline $\mathrm{pH}$ & -0.5 & -0.55 & 0.53 & -0.3 & -0.44 & 1 & & & & & & & & & & & & & & \\
\hline Specific conductivity & 0.56 & 0.51 & -0.12 & 0.95 & 0.35 & -0.37 & 1 & & & & & & & & & & & & & \\
\hline TDS & 0.62 & 0.59 & -0.08 & 0.95 & 0.33 & -0.3 & 0.92 & 1 & & & & & & & & & & & & \\
\hline ORP & 0.57 & 0.6 & -0.74 & 0.11 & 0.46 & -0.84 & 0.18 & 0.11 & 1 & & & & & & & & & & & \\
\hline Phosphorus & -0.44 & -0.42 & 0.68 & -0.29 & -0.51 & 0.2 & -0.36 & -0.33 & -0.38 & 1 & & & & & & & & & & \\
\hline Number of species & 0.53 & 0.46 & -0.33 & 0.6 & 0.14 & -0.27 & 0.61 & 0.57 & 0.28 & -0.21 & 1 & & & & & & & & & \\
\hline Total abundance & -0.6 & -0.53 & 0.16 & -0.62 & -0.15 & 0.22 & -0.61 & -0.57 & -0.19 & 0.16 & -0.65 & 1 & & & & & & & & \\
\hline Calanoida & -0.59 & -0.56 & 0.22 & -0.68 & -0.24 & 0.39 & -0.69 & -0.68 & -0.37 & 0.25 & -0.54 & 0.68 & 1 & & & & & & & \\
\hline Cladocera & -0.55 & -0.5 & 0.09 & -0.38 & -0.05 & 0.15 & -0.34 & -0.32 & -0.17 & 0.13 & -0.42 & 0.73 & 0.55 & 1 & & & & & & \\
\hline Larvae & -0.32 & -0.26 & 0.07 & -0.32 & -0.04 & 0.01 & -0.3 & -0.25 & 0.02 & 0.03 & -0.47 & 0.82 & 0.16 & 0.48 & 1 & & & & & \\
\hline Cnidaria & -0.46 & -0.41 & -0.01 & -0.56 & -0.08 & 0.1 & -0.57 & -0.51 & -0.14 & 0.08 & -0.41 & 0.45 & 0.71 & 0.54 & 0 & 1 & & & & \\
\hline Decapoda & -0.56 & -0.51 & 0.05 & -0.51 & -0.11 & 0.08 & -0.48 & -0.48 & -0.17 & 0.01 & -0.56 & 0.6 & 0.33 & 0.2 & 0.56 & 0.31 & 1 & & & \\
\hline Net & -0.69 & -0.66 & 0.66 & -0.57 & -0.5 & 0.49 & -0.62 & -0.6 & -0.6 & 0.54 & -0.67 & 0.57 & 0.45 & 0.22 & 0.45 & 0.22 & 0.69 & 1 & & \\
\hline Nano & -0.76 & -0.73 & 0.48 & -0.51 & -0.33 & 0.55 & -0.48 & -0.4 & -0.62 & 0.43 & -0.5 & 0.56 & 0.58 & 0.59 & 0.29 & 0.46 & 0.27 & 0.52 & 1 & \\
\hline Pico & -0.54 & -0.52 & 0.73 & -0.44 & -0.45 & 0.66 & -0.47 & -0.35 & -0.7 & 0.5 & -0.58 & 0.48 & 0.44 & 0.28 & 0.33 & 0.18 & 0.3 & 0.71 & 0.69 & 1 \\
\hline
\end{tabular}

All marked station correlations are significant at $p<0.05000, N=40$ (casewise deletion of missing data). Significant correlations indicated by coefficient of determination values $\geq 0.50$. 

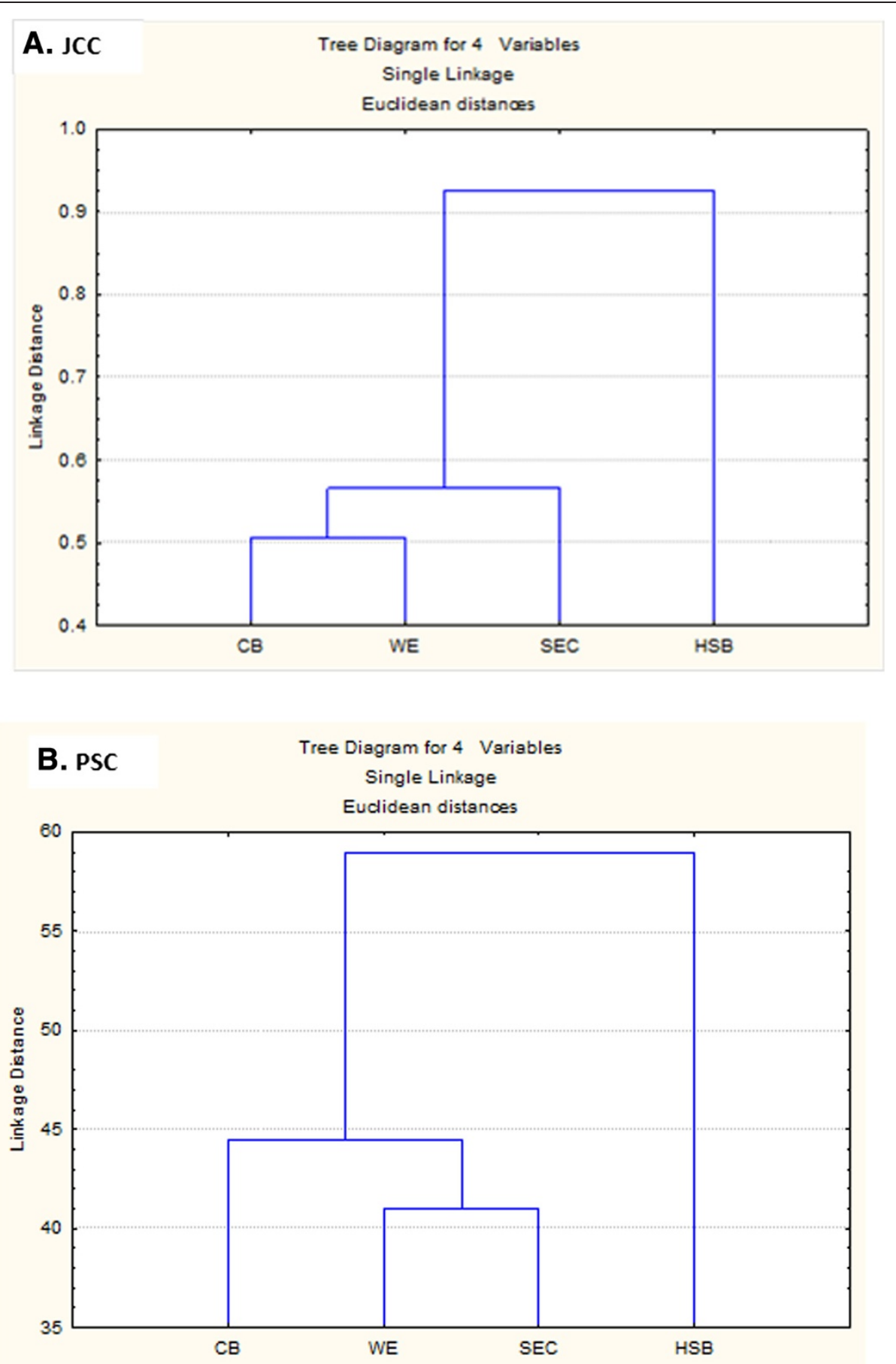

Figure 8 Dendrogram showing the mean station association using (A) JCC and (B) PSC. HSB, Harbour Shoal Beacon; SEC, South-East Cay; WE, Windward Edge; CB, California Bank.

offshore. The study was also intended to use the zooplankton as indicators of different water masses with differing trophic conditions. Previous studies have used the physicochemical parameters and chlorophyll $a$ (Vollenweider et al. 1998; Fehling et al. 2012) or the zooplankton (e.g. Hwang and Heath 1997; Lougheed and
Chow-Fraser 2001; Hwang et al. 2006, 2010) to characterize the trophic status and water quality of marine areas. However, in this study, the physicochemical parameters were found to be unreliable with key parameters either not showing significant spatial differences (e.g. nitrates, turbidity) or not having the expected trend of decreasing/ 
Table 5 Jaccard community coefficient (JCC) and percentage community coefficient (PSC) values for the four stations

\begin{tabular}{cccccc}
\hline & Station & HSB & SEC & WE & CB \\
\hline \multirow{4}{*}{ JCC } & HSB & 1 & & & \\
& SEC & 0.378 & 1 & & \\
& WE & 0.360 & 0.626 & 1 & \\
& CB & 0.348 & 0.463 & 0.661 & 1 \\
\hline \multirow{4}{*}{ PSC } & HSB & 100 & & & \\
& SEC & 60.19 & 100 & & \\
& WE & 55.52 & 72.14 & 100 & \\
& CB & 53.70 & 59.44 & 69.89 & 100
\end{tabular}

HSB, Harbour shoal beacon; SEC, South-East cay; WE, Windward edge; $C B$, California bank.

increasing with distance offshore (e.g. temperature/salinity, phosphates, specific conductance). The zooplankton were therefore expected to be useful indicators of the different water masses along the Harbour, shelf and offshore gradient by showing lower taxonomic richness/diversity coupled with higher abundances at the eutrophic Harbour station, progressing to higher richness/diversity with lower abundance at the shelf and offshore areas (Zhang et al. 2009). Individual zooplankton taxa by the variation in their abundance and percentage occurrence were also expected to indicate the different water masses.

\section{Taxonomic richness and diversity}

The number of species (taxonomic richness) and diversity were expected to show significant variation between stations, with the highest values at stations furthest offshore (WE and CB) and lowest at the mouth of Kingston Harbour (HSB), and SEC being an intermediary along the eutrophication gradient (Zervoudaki et al. 2009; Zhang et al. 2009). However, while SEC and WE were similar in terms of richness and diversity values, HSB and $\mathrm{CB}$ were also similar. Due to the distances involved, it is unlikely that taxonomic similarities between these stations were indicative of a common water mass. SEC and WE are likely to be enriched by waters of the south coast shelf as well as upwelled nutrients as both are associated with the edge of the south-east coast shelf, beyond which depths immediately fall from 44 to $347 \mathrm{~m}$, or the edge of the Port Royal Cays area, beyond which depths fall from 5.8 to $31 \mathrm{~m}$ (Admiralty Chart number 456, 1992). California Bank, while not associated with the island shelf, would also come under the influence of enrichment from upwelled waters as it rises to $30 \mathrm{~m}$ from the ocean floor depths of $245 \mathrm{~m}$. The increase in nitrates and phosphates confirm nutrient enrichment which would influence taxonomic richness and diversity. The effect of these upwelled waters at the offshore bank with the associated increase in zooplankton parameters and decrease in diversity, would lead to the bank being classified as mesotrophic rather than oligotrophic.

The community indices, Jaccard community coefficient and percentage similarity coefficient, in conjunction with the cluster analyses also showed a general similarity between stations SEC, WE and CB and a high dissimilarity of that group with station HSB. Webber et al. (1996) identified the Harbour mouth as a discrete region with different characteristics from other areas on the Jamaican south coast shelf which included the South-East Cay. The harbour mouth region comes under the direct influence of waters originating from the Kingston Harbour, which has for a long time been considered a source of eutrophic waters (Moore and Sander 1979; Webber et al. 1996; Dunbar and Webber 2003; Webber and Wilson-Kelly 2003). In the present study, the community composition clearly separated the Harbour mouth station from the shelf and offshore areas.

\section{Zooplankton abundance}

The highest mean zooplankton abundances would be expected from station HSB at the Harbour mouth with lower abundances at the stations outside of the influence of the harbour. Moore and Sander (1979) observed this trend, with numbers at their harbour mouth station (3 J) being the highest overall, with the lowest numbers being recorded off the shelf (station $1 \mathrm{~J}$ ). Hopcroft and Roff (2003) reported that the availability of nutrients plays an important role in varying phytoplankton populations and inherently zooplankton numbers. The high availability of nutrients due to the proximity to sources of nutrient input (Webber and Wilson-Kelly 2003) would lead to a highly productive phytoplankton community able to support a large zooplankton community at HSB. The outer stations would be considered nutrient deficient as sources of input are minimal and nutrient concentrations typically low (Moore and Sander 1979; Hopcroft and Roff 2003). At these stations, local processes and the upwelling of nutrients would be the main factors controlling the numbers of zooplankton.

Moore and Sander (1979) had reported 450.5 individuals $\mathrm{m}^{-3}$ for their offshore site $(1 \mathrm{~J})$, which was approximately one fifth of what was reported during this study at $\mathrm{CB}$ $\left(2,125 \mathrm{~m}^{-3}\right)$. While 40 years separate the two studies, we believe such a large increase in abundances is more likely due to differences in sampling methods rather than solely to increased enrichment and productivity at the offshore stations. Higher numbers in the present study could be because station $\mathrm{CB}$ was located above an underwater bank, which could disrupt the current flow and cause vertical mixing and introduction of nutrients into the surface waters. Carleton et al. (2001) also found that interference of water currents by banks affected zooplankton communities, whereby higher numbers were found but with similar 
richness when compared to offshore sites not associated with banks.

It was expected that copepods would be numerically dominant, as has been reported by numerous authors (Moore and Sander 1979; Youngbluth 1980; Chisholm and Roff 1990; Webber et al. 1996; Dunbar and Webber 2003; Hsieh et al. 2004; Lan et al. 2004; Hwang et al. 2006). However, larvae were numerically dominant at three of the four stations, with numbers being higher than all other taxa combined at CB. The copepods were the second most dominant taxon at all stations except $\mathrm{WE}$, where their numbers exceeded the larvae. This dominance of copepods and larvae was also reported by Hwang et al. (2010) from the Danshuei Ecosystem of northern Taiwan, an area with riverine, estuarine and marine conditions. The dominance of larval forms at the offshore bank (station CB) further supports the area as having high biological productivity (Heywood et al. 1990; Hernández-León 1991). Furthermore, the high numbers of passive zooplankton, mainly fish eggs, echinoderms and mollusc larvae, would suggest reduced flushing at these sites. A few authors have noted that circulation patterns near submerged structures, such as banks, could lead to retention and increased numbers of especially larval forms with limited means of movement (Cowen and Castro 1994; Carleton et al. 2001).

\section{Indicator species}

Within each taxonomic group, a few species displayed significant variation in abundance and percentage occurrence across stations. These species were identified as indicators of different water masses. $P$. avirostris and L. faxoni have previously been identified as indicators of Kingston Harbour waters in previous studies, and these species have been again shown to characterize the waters at the harbour mouth. In addition, $M$. norvegica and $F$. carinata are now being identified as indicators of offshore waters, using percentage occurrence and abundance.

The cladoceran $P$. avirostris has been previously reported in high numbers in Kingston Harbour (Moore and Sander 1979; Dunbar and Webber 2003). The distribution of the species appears to be affected by salinity and food availability. Moraitou-Apostolopoulou and Kiortsis (1973) found that salinity and water depth had an effect on the distribution of $P$. avirostris, thereby limiting its presence to shallow areas with low-salinity waters, like Kingston Harbour. The Harbour is influenced by freshwater and high nutrient input from various sources (Webber et al. 2003; Webber and Wilson-Kelly 2003). P. avirostris generally feeds on particles $<15 \mu \mathrm{m}$ (Lipej et al. 1997), and within the Harbour, the most suitable size phytoplankton (nano-plankton 2 to $20 \mu \mathrm{m}$ ) would be readily available (Ranston et al. 2003).
The distribution of $L$. faxoni also appears to be affected by salinity levels, and therefore, L. faxoni has been found to be abundant near areas with freshwater inputs (Webber et al. 2005). Moore and Sander (1979) did not report the species at their offshore stations, but it was reported at their harbour stations with similar mean abundance values to the present study. Lindo (1991) and Webber et al. (1996) reported this species as being numerically dominant with maximum numbers at the mouth of the Harbour. Rakhesh et al. (2006) noted that salinity was important in affecting zooplankton assemblage, and the enrichment of coastal waters by fluvial inputs led to changes in the phytoplankton which in turn affected the zooplankton. In this study, phytoplankton size classes correlated with the number of species and total abundance of zooplankton.

The copepod $M$. norvegica which is now being proposed as an indicator of the offshore stations was previously reported by Moore and Sander (1979) as occurring only at stations outside of the Harbour, while Chisholm and Roff (1990) did not record M. norvegica in their study of the cays area near Kingston Harbour. Webber and Roff (1995) reported M. norvegica as accounting for $2 \%$ of the total copepod abundance at their offshore station in Discovery Bay, Jamaica. Another proposed offshore indicator, the copepod $F$. carinata, was also found to be important in oceanic waters off the north coast at Discovery Bay, Jamaica by Webber and Roff (1995).

The indices used (species composition, community similarity indices, species density, total zooplankton abundance and individual indicator species) gave clear indication of the variation in distribution of the zooplankton communities in inshore, shelf and oceanic waters. In general, there was an increase in the species richness with a concomitant decrease in the abundance towards the open sea. The trend observed was similar to that caused by the island mass effect, and based on these indices, the identification of different areas with different levels of eutrophication was possible. It indicated that station HSB is the most eutrophic site, but there was no consistent pattern of increasing oligotrophic conditions with increasing distance from Kingston Harbour.

When all the indices were considered, the most pristine station was WE followed by SEC, both located on the south-east coast shelf. Although furthest offshore, $\mathrm{CB}$ showed signs of enrichment and therefore could not be considered as oligotrophic. While the current study therefore showed that there were significant differences between oceanic, shelf and Harbour waters off Jamaica's south-east coast, the inclusion of an offshore bank indicated that offshore areas with features such as banks support zooplankton communities that may be similar to the shelf area. Thus, these banks would be more accurately characterized as mesotrophic. 


\section{Conclusions}

While the expectation of the study was to separate the water masses into oceanic, shelf and Harbour waters, along a eutrophication gradient, most indices identified only two contrasting water masses (eutrophic Kingston Harbour and mesotrophic shelf/offshore bank). The water masses were best separated using taxonomic richness, total zooplankton abundance and community similarity. Four species were also identified as good indicators of the water masses of the area. These were $L$. faxoni and $P$. avirostris, indicators of eutrophic Kingston Harbour waters, and M. norvegica and F. carinata, indicators of mesotrophic shelf and offshore waters.

\section{Abbreviations}

SCOR: Scientific Committee on Oceanic Research; UNESCO: United Nations Educational, Scientific and Cultural Organization.

\section{Competing interests}

The authors declare that they have no competing interests.

\section{Authors' contributions}

MKW designed the investigation, while sampling and analysis was conducted by KAL. Both authors conducted the data analysis and prepared the figures and manuscript, but MKW finalized and submitted the latter. Both authors read and approved the final manuscript.

\section{Acknowledgements}

We are grateful for the funding provided by the University of the West Indies (UWI). Invaluable sampling assistance was provided by Hugh Small of the Port Royal Marine Laboratory, UWI.

\section{Received: 3 December 2013 Accepted: 27 March 2014}

\section{Published: 29 April 2014}

\section{References}

Aiken KA, Kong GA (2000) The marine fisheries of Jamaica. The ICLARM Quarterly 23:29-35

Campbell P, Manning J, Webber M, Webber D (2008) Planktonic communities as indicators of water quality in mangrove lagoons; a Jamaican case study. Trans Waters Bull 3:39-63

Carleton JH, Brinkman R, Doherty PJ (2001) Zooplankton community structure and water flow in the lee of Helix Reef (Great Barrier Reef, Australia). Mar Biol 139:705-763

Chisholm L, Roff JC (1990) Abundance, growth rates, and production of tropical neritic copepods off Kingston, Jamaica. Mar Biol 106:79-89

Clifford TT, Stephenson NW (1975) An introduction to numerical classification. Academic, London

Cowen RK, Castro LR (1994) Relation of coral reef fish larval distributions to island scale circulation around Barbados, West Indies. Bull Mar Sci 54:228-244

Dunbar FN, Webber MK (2003) Zooplankton distribution in the eutrophic Kingston Harbour, Jamaica. Bull Mar Sci 73:343-359

Fehling J, Davidson K, Bolch CJS, Brand TD, Narayanaswamy BE (2012) The relationship between phytoplankton distribution and water column characteristics in North West European shelf sea waters. PLOS ONE 7:1-14, doi:10.1371/journal.pone.003498, e34098

Francis P, Maxam S, Webber MK (2013) Rapid reassessment of the eutrophic Kingston Harbour, Jamaica using the zooplankton community., Paper presented at the 36 th scientific meeting of the Association of Marine Laboratories of the Caribbean - AMLC, Discovery Bay Marine Laboratory (UWI), St. Ann, 17-21 June 2013

Grahame J (1976) Zooplankton of a tropical harbour: the numbers, composition and response to physical factors of zooplankton in Kingston Harbour, Jamaica. J Exp Mar Bio Ecol 25:219-237

Hernández-León S (1988) Gradients of mesozooplankton biomass and ETS activity in the wind-shear area as evidence of an island mass effect in the Canary Island waters. J Plank Res 10:1141-1154
Hernández-León S (1991) Accumulation of mesozooplankton in a wake area as a causative mechanism of the "island-mass effect". Mar Biol 109:141-147

Hernandez-Leon S, Almeida C, Gomex M, Torres S, Montero I, Portillo-Hahnefeld A (2001) Zooplankton biomass and indices of feeding and metabolism in island-generated eddies around Gran Canaria. J Mar Syst 30:51-66

Heywood KJ, Barton ED, Simpson JH (1990) The effects of flow disturbance by an oceanic island. J Mar Res 48:55-73

Hopcroft RR, Roff JC (2003) Response of tropical marine phytoplankton communities to manipulations of nutrient concentration and metazoan grazing pressure. Bull Mar Sci 73:397-420

Hsieh C-H, Chiu T-S, Shih C (2004) Copepod diversity and composition as indicators of intrusion of the Kuroshio Branch Current into the Northern Taiwan Strait in Spring 2000. Zool Stud 43:393-403

Hwang J-S, Heath RT (1997) The distribution of protozoa across a trophic gradient, factors controlling their abundance and importance in the plankton food web. J Plank Res 19:491-518

Hwang J-S, Souissi S, Tseng L-C, Seuront L, Ois O, Schmitt G, Fang L-S, Peng S-H, Wu C-H, Hsiao S-H, Twan W-H, Wei T-P, Kumar R, Fang T-H, Chen Q-C, Kim Wong C (2006) A 5-year study of the influence of the northeast and southwest monsoons on copepod assemblages in the boundary coastal waters between the East China Sea and the Taiwan Strait. J Plank Res 28:943-958

Hwang J-S, Kumar R, Hsieh C-W, Kuo AY, Souissi S, Hsu M-H, Wu J-T, Liu W-C, Wang C-F, Chan Q-C (2010) Patterns of zooplankton distribution along the marine estuarine and riverine portions of the Danshuei ecosystem in northern Taiwan. Zool Stud 49:335-352

Kwiatkowski RE, Roff JC (1976) Effects of acidity on the phytoplankton and primary productivity of selected northern Ontario lakes. Can J Fish Aquat Sci 54:2546-2561

Lan Y-C, Shih C, Lee M-A, Sheih H-Z (2004) Spring distribution of copepods in relation to water masses in the northern Taiwan Strait. Zool Stud 43:332-343

Lindo MK (1991) The effect of Kingston Harbour outflow on zooplankton populations of Hellshire, south-east coast, Jamaica. Est Coast Shelf Sci 32:597-608

Lipej L, Mozetič P, Turk V, Malej A (1997) The trophic role of the marine cladoceran Penilia avirostris in the Gulf of Trieste. Hydrobiol 360:197-203

Lougheed V, Chow-Fraser P (2001) Development and use of a zooplankton index of wetland quality in the Laurentian Great Lakes basin. Ecol Apps 12:474-486

Moore E, Sander F (1979) A comparative study of zooplankton from oceanic, shelf, and harbour waters of Jamaica. Biotrop 11:196-206

Moraitou-Apostolopoulou M, Kiortsis V (1973) The cladocerans of the Aegean sea: occurrence and seasonal variation. Mar Biol 20:137-143

Narinesingh D (2007) Numerical modeling of physical oceanographic features of the southeast Palisadoes coastal shelf of Jamaica (WI).. PhD Dissertation, University of the West Indies

Parsons T, Maita Y, Lalli C (1984) A manual of chemical and biological methods for seawater analysis. Pergamon, Oxford

Persad G, Hopcroft RR, Webber MK, Roff JC (2003) Abundance, biomass and production of ctenophores and medusae off Kingston, Jamaica. Bull Mar Sci 73:379-396

Rakhesh MA, Raman V, Sudarsan D (2006) Discriminating zooplankton assemblages in neritic and oceanic waters: a case for the northeast coast of India, Bay of Bengal. Mar Envr Res 6:93-109

Ranston E, Simmonds R, Webber D (2003) The phytoplankton distribution in Kingston Harbour. Bull Mar Sci 73:325-342

Sander F (1981) A preliminary assessment of the main causative mechanisms of the "island mass" effect of Barbados. Mar Biol 64:199-205

Sander F, Steven D (1973) Organic productivity of inshore and offshore waters of Barbados: a study of the island mass effect. Bull Mar Sci 23:771-792

Small HC, Lue KA, Webber D, Webber M (2013) The planktonic communities of the Jamaican south-east coast; a comparison of harbour, shelf and oceanic areas., Paper presented at the 36th scientific meeting of the Association of Marine Laboratories of the Caribbean - AMLC, Discovery Bay Marine Laboratory (UWI), St. Ann, 17-21 June 2013

UNESCO (1968) Monographs on oceanic methodology 2: zooplankton sampling. UNESCO, Paris

Van Guelphen L, Markle D, Duggan D (1982) An evaluation of the accuracy, precision, and speed of several zooplankton sub-sampling techniques. J Cons Perm Int Explor Mer 40:222-236

Vollenweider RA, Giovanardi F, Montanari G, Rinaldi A (1998) Characterisation of the trophic conditions of marine coastal waters with special reference to the NW Adriatic Sea: proposal for a trophic scale, turbidity and generalized water quality index. Environmetrics 9:329-357 
Webber MK, Roff JC (1995) Annual structure of the copepod community and its associated pelagic environment off Discovery Bay, Jamaica. Mar Biol 123:467-479

Webber DF, Wilson-Kelly P (2003) Characterization of sources of organic pollution to Kingston Harbour, the extent of their influence and some rehabilitation recommendations. Bull Mar Sci 73:257-271

Webber MK, Roff JC, Chisholm LA, Clarke CA (1996) Zooplankton distributions and community structure in an area of the south coast shelf of Jamaica. Bull Mar Sci 59:259-270

Webber DF, Webber MK, Williams DD (2003) The relative importance of meteorological events, tidal activity and bathymetry to circulation and mixing in Kingston Harbour, Jamaica. Bull Mar Sci 72:273-289

Webber MK, Edward-Myers E, Campbell C, Webber D (2005) Phytoplankton and zooplankton as indicators of water quality in discovery Bay, Jamaica. Hydrobio 545:177-193

Youngbluth MJ (1980) Daily, seasonal, and annual fluctuations among zooplankton populations in an unpolluted tropical embayment. Est Coast Mar Sci 10:265-287

Zervoudaki S, Nielsen TG, Carstensen J (2009) Seasonal succession and composition of the zooplankton community along an eutrophication and salinity gradient exemplified by Danish waters. J Plank Res 31:1475-1492

Zhang W, Tang D, Yang B, Gao S, Sun J, Tao Z, Sun S, Ning X (2009) Onshoreoffshore variations of copepod community in northern South China Sea. Hydrobiol 636:257-269. doi:10.1007/s10750-009-9955-x

doi:10.1186/s40555-014-0018-2

Cite this article as: Lue and Webber: A new comparative study of zooplankton from oceanic, shelf and harbour waters, south-east coast, Jamaica. Zoological Studies 2014 53:18.

\section{Submit your manuscript to a SpringerOpen ${ }^{\circ}$ journal and benefit from:}

- Convenient online submission

- Rigorous peer review

- Immediate publication on acceptance

- Open access: articles freely available online

- High visibility within the field

- Retaining the copyright to your article

Submit your next manuscript at $\gg$ springeropen.com 